\title{
Oxidative Synthesis of Activated Carbon from Low-grade Indian Tertiary Coal and Its Chemical Characterization
}

\author{
Phibarisha Sohtun¹, Mousumi Bora², Rupam Kataki1,, , Binoy K. Saikia2,† \\ ${ }^{1}$ Department of Energy, Tezpur University, Tezpur, Assam 784028, India \\ ${ }^{2}$ Coal \& Energy Group, Materials Science \& Technology Division, CSIR-NEIST, Jorhat, Assam 785006, India
}

\begin{abstract}
(Received 21 March 2021; revised manuscript received 12 June 2021; published online 25 June 2021)
Carbon materials have unique structural and chemical properties attracting for applications in various fields. Coal is available in abundance and a low-cost energy source. Coal is a major source of carbon which can be used as a precursor to derive value-added carbon products and thereby, enhances its effective utilization in a sustainable manner. In this study, activated carbons were prepared from tertiary coal obtained from North-eastern region of India. The preparation process consisted of pre-treatment of coal by oxidation followed by mixed alkali impregnation and carbonization at $600{ }^{\circ} \mathrm{C}$. The synthesized samples were characterized using proximate and ultimate analysis, sulfur analysis, surface area and pore size analysis, transmission electron microscopy (TEM), Fourier transform infrared spectroscopy (FTIR), and powder X-ray diffraction (XRD) analysis. The results reveal that the produced activated carbons have improved specific surface area and pore size after chemical activation, and they are amorphous, micro-mesoporous in nature. Thus, the low-grade Indian tertiary coals are a potential source to derive activated carbon based high value-added carbon products.
\end{abstract}

Keywords: Carbon material, Indian coal, Tertiary coal, Chemical activation, Activated carbon.

\section{INTRODUCTION}

Carbon based materials demonstrate good chemical and physical properties due to their structural diversity making it an interesting active material. Coal is an important energy resource around the world, which is available in abundance, and due to its readily combustible nature, it is widely used for generation of power throughout the globe. However, coal is also used as carbon precursor due to its rich carbon content, abundant reserves, low cost, and huge supply.

Coals available at North-eastern region of India are subbituminous Tertiary coals which contain trace elements, mineral matters, high sulfur content, volatile matter, and less ash content [1]. Coal is widely used as it can produce highly porous activated carbon during carbonization and activation methods and this in turn maximizes the efficient usage of coal [2].

\section{MATERIALS AND METHODS}

\subsection{Materials}

Raw North-east Indian coal sample was obtained from Coal and Energy Group, Materials Science and Technology Division (MSTD), CSIR-NEIST, Jorhat, Assam. The samples were crushed, ground, and sieved using ASTM standard methods.

\subsection{Method}

The experiments were carried out in an ambient condition. The detailed methodology was reported in our previous study [3, 4].

\subsection{Analytical Characterization of Raw Coal and Activated Carbon}

The proximate analysis and total sulfur analysis of coal samples were performed using Thermogravimetric Analyzer (Leco TGA701) and Dual Range Sulfur Analyzer (Leco S-144DR) (accuracy \pm 0.02 ), respectively. The ultimate $(\mathrm{C}, \mathrm{H}, \mathrm{N})$ analysis was performed in Truspec CHN Macro Determinator (630-100-300) each following ASTM standard methods. Fourier transform infrared spectrophotometer (PerkinElmer, Spectrum 100) using $\mathrm{KBr}$ pellet method was used to collect the FTIR spectral data of the coal samples. Powder X-ray Diffractometer (Rigaku, ULTIMA IV) using CuKa source $(\lambda=0.154 \mathrm{~nm})$ was used to record the XRD spectra of raw coal and activated carbon. The surface area and pore size were performed in Autosorb-iQ (Quantachrome, USA) using BET and BJH method by nitrogen adsorption-desorption isotherms at $77.35 \mathrm{~K}$. Transmittance electron microscope (JEOL, JEM-2100 PlusElectron Microscope) was used to observe the morphology of the coal samples.

\section{RESULTS AND DISCUSSION}

\subsection{Physico-chemical Analysis}

Table 1 illustrates the physico-chemical characteristics of raw, oxidized and coal derived activated carbon. Raw coal has high moisture content (11.92\%). However, little variation has been observed in the amount of moisture content $(11.70 \%)$ present in the activated coal. The moisture content of the activated carbon had increased possibly due to adsorption of moisture from the air, during the washing process. The

\footnotetext{
*rupam@tezu.ernet.in

† bksaikia@neist.res.in

The results were presented at the International Conference on Innovative Research in Renewable Energy Technologies (IRRET-2021)
} 
ash content $(6.55 \%)$ of the coal derived activated carbon had probably increased because of mineral matter present in coal. The volatile matter has reduced to a great extent for the activated coal which is conducive for pore formation. The high carbon content (78.19\%) of raw coal favors its use as precursor material for activated carbon. The fixed carbon content and carbon content have increased in the activated coal with reduced hydrogen content after chemical activation and high temperature treatment. There is a decrease in the total sulfur content of coal derived activated carbon. However, the degree to which sulfur could be removed from coal depends upon its rank [9].

Table 1 - Physicochemical characteristics of coal samples

\begin{tabular}{|l|c|c|c|c|c|c|c|}
\hline \multirow{2}{*}{ Sample } & \multicolumn{4}{|c|}{ Proximate Analysis (\%) } & \multicolumn{3}{c|}{ Ultimate Analysis (\%) } \\
\cline { 2 - 8 } & Moisture & $\begin{array}{c}\text { Volatile } \\
\text { Matter }\end{array}$ & Ash & $\begin{array}{c}\text { Fixed } \\
\text { Carbon }\end{array}$ & Carbon & Hydrogen & $\begin{array}{c}\text { Total } \\
\text { Sulphur }\end{array}$ \\
\hline RJC01 & 11.92 & 42.11 & 2.67 & 43.29 & 78.19 & 6.43 & 2.94 \\
\hline 0JC01 & 4.20 & 48.82 & 2.95 & 44.02 & 80.91 & 5.54 & 2.90 \\
\hline AJC01 & 11.70 & 13.71 & 6.55 & 62.57 & 85.18 & 2.81 & 2.10 \\
\hline RJC01: Raw coal; 0JC01: Oxidised coal; AJC01: Activated carbon \\
\hline
\end{tabular}

\subsection{BET Surface Area and Pore Size Distribution Analysis}

The Brunauer-Emmett-Teller (BET) specific surface area analysis illustrates that raw coal has a specific surface area of $22.199 \mathrm{~m}^{2} \mathrm{~g}^{-1}$ whereas coal derived activated carbon has a specific surface area of $93.932 \mathrm{~m}^{2} \mathrm{~g}^{-1}$. The Barrett-Joyner-Halenda (BJH) method used to derive the pore size distribution indicates that the materials are mesoporous in nature. Raw coal and activated coal have an average pore size of $3.548 \mathrm{~nm}$ and $3.533 \mathrm{~nm}$ and average pore volume of $0.043 \mathrm{ccg}^{-1}$ and $0.005 \mathrm{ccg}^{-1}$, respectively. The specific surface area of the resultant activated carbon increased after chemical activation.

Fig. 1 displays nitrogen adsorption-desorption isotherms of coal samples. According to the BET classification, the adsorption isotherm of raw coal belongs to type III. At higher relative pressure $\left(P / P_{0}>0.45\right)$ the isotherm displays a prominent hysteresis loop [5]. The adsorption isotherm of activated coal shows the type I and type IV isotherm. A type I isotherm associated with micropores was observed at lower relative pressures and at increasing relative pressures; the isotherm of type IV which correlates to adsorption in mesopores was observed [6].
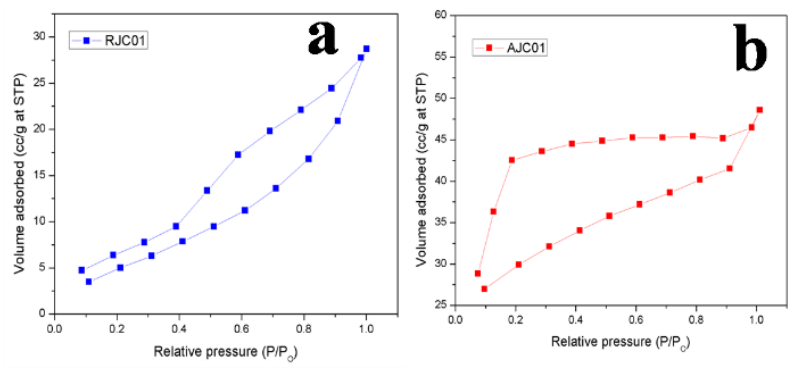

Fig. 1 - Nitrogen adsorption-desorption isotherm of (a) raw coal (RJC01), (b) activated carbon (AJC01)

\subsection{Functional Group Detection of Raw Coal}

\section{and Activated Carbon}

The FTIR spectrum (Fig. 2) of raw, oxidized, and activated coal was analyzed. The stretching vibration peak present in between the 3500 to $3200 \mathrm{~cm}^{-1}$ frequency range indicates the presence of $\mathrm{N}-\mathrm{H}$ and $\mathrm{O}-\mathrm{H}$ groups with classes of compounds primary and secondary amines, amide. The peaks present between the frequency ranges of 3000 to $2850 \mathrm{~cm}^{-1}$ indicates the presence of $\mathrm{CH}_{3}, \mathrm{CH}_{2}$, and $\mathrm{CH}$ groups with long aliphatic chains [7]. The absorbance in this band has found to decrease in activated carbon. The region between 1760 to $1665 \mathrm{~cm}^{-1}$ corresponds carbonyl $(\mathrm{C}=\mathrm{O})$ groups, stretching vibration peaks are present with classes of compounds containing aldehyde, ketone, carboxylic acid, esters. Stretching vibration peak present in between 1680 to $1640 \mathrm{~cm}^{-1}$ range assigned to vinylic $\mathrm{C}=\mathrm{C}$ and aromatic $\mathrm{C}=\mathrm{C}$ possibly because of the presence of other functional groups containing oxygen which comprises of ethers, alcohols, phenols, carbonyls, and carboxylic acid [8]. Stretching vibration peak present in between 1500 to $1400 \mathrm{~cm}^{-1}$ range indicates $\mathrm{C}-\mathrm{C}$ group with aromatic compounds. The bending vibration peaks present between the range of $1470 \mathrm{~cm}^{-1}$ to $1450 \mathrm{~cm}^{-1}$ frequency indicates $\mathrm{C}-\mathrm{H}$ group with class of compound containing alkane. The frequency range of 1320 to $1000 \mathrm{~cm}^{-1}$ attributed to $\mathrm{C}-\mathrm{O}$ bonds in coal spectra [7]. Potassium bromide was used in the preparation of the samples as pellets, and it was indicated in the stretching vibration peak in the range between 650 and $515 \mathrm{~cm}^{-1}$ attributing $\mathrm{C}-\mathrm{Br}$ group with alkyl halides compounds present in all the coal samples.

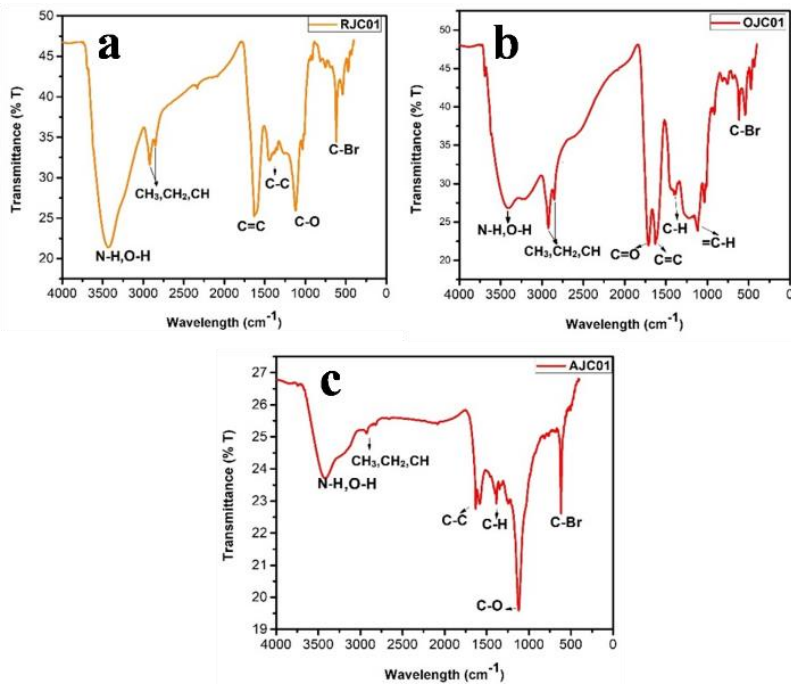

Fig. 2 - FTIR spectra of (a) raw coal (RJC01), (b) oxidized coal (OJC01), (c) activated carbon (AJC01)

\subsection{Powder X-ray Diffraction (XRD)}

The XRD spectra (Fig. 3) of raw coal show a broad and weak peak at $2 \theta$ values of around 23.26 degree. The XRD pattern of activated coal shows three peaks at $2 \theta$ values of $11.6,23.8$ and 43.03 degree. The unusual peak at 11.6 degree indicates the presence of functional groups containing oxygen and water molecules in the carbon material. The two low, broad intensity diffraction peaks at 23.8 and 43.03 degree correspond to the 
(002) and (100) diffraction patterns. The peak appeared for activated carbon at 43.03 degree indicated the development of increasingly carbonized material and gives evidence of the presence of amorphous graphitic structure. The XRD analysis shows that the prepared activated carbons are amorphous in nature [9, 10].
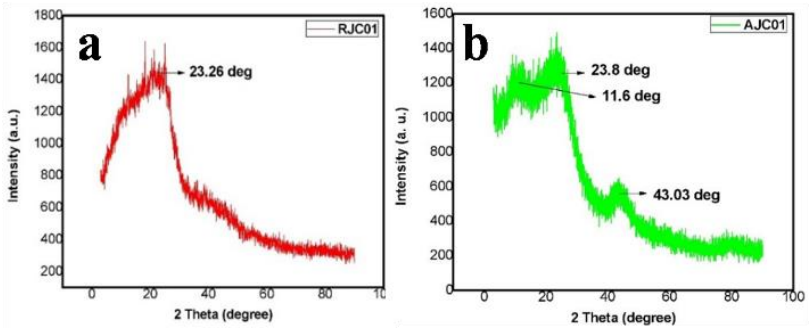

Fig. 3 - XRD spectra of (a) raw coal (RJC01), (b) activated carbon (AJC01)
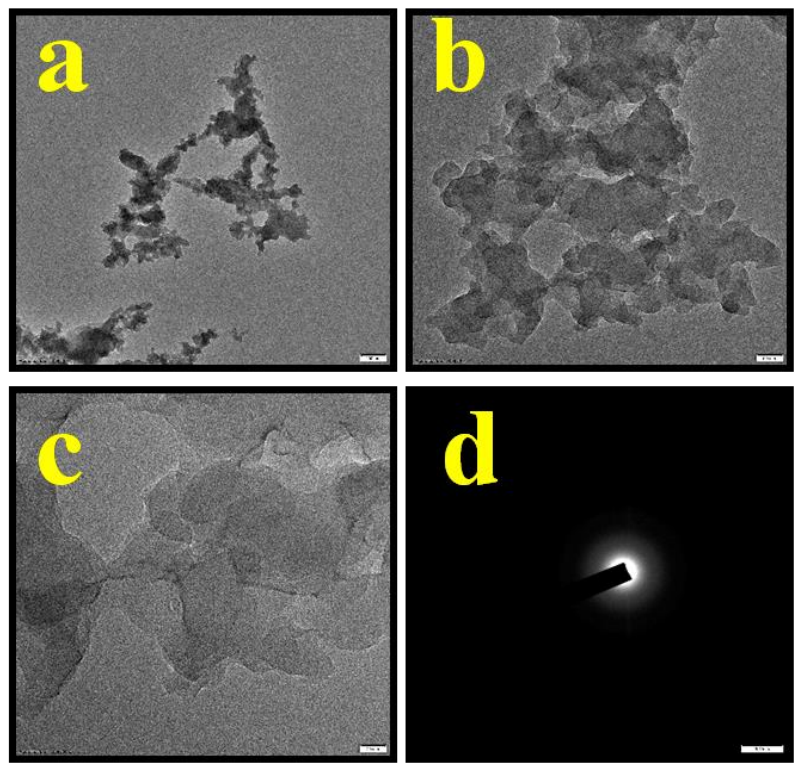

Fig. 4 - (a, b, c) HR-TEM images of raw coal, (d) SAED image of raw coal

\subsection{Morphological (HR-TEM) Analysis}

HR-TEM analysis of RJC01 (raw coal) without alkali treatment shows the absence of pores in the coal product as observed from Fig. 4a, b, c. Coal-derived activated carbon has spherical, porous structures as observed from Fig. 5. SAED (Selected Area Electron Diffraction) pattern of raw coal, Fig. 4d, exhibits typical diffuse rings. The coal-derived activated carbon was amorphous

\section{REFERENCES}

1. C. Mayuri, O.P. Singh, Int. J. Coal. Sci. Technol. 3, 87 (2016).

2. I. Suárez-Ruiz, J.C. Crelling, Appl. Coal. Petrolog. 193 (2008).

3. S. Mukherjee, S. Mahiuddin, P.C. Borthakur, Energ. Fuel. 15, No 6, 1418 (2001).

4. M. Bor, S.M. Benoy, J. Tamuly, B.K. Saikia, J. Env. Chem. Eng. 9, 104986 (2021).

5. F. Yan-Yan, Y. Wen, C. Wei, Chin. Phys. B 25 No 6, 068102 (2016).

6. A. Kumar, H.M. Jena, Res. Phys. 6, 651 (2016). in nature from HR-TEM as well as from XRD results. Abundant meso-micropores can be observed that agrees well with the nitrogen adsorption data.
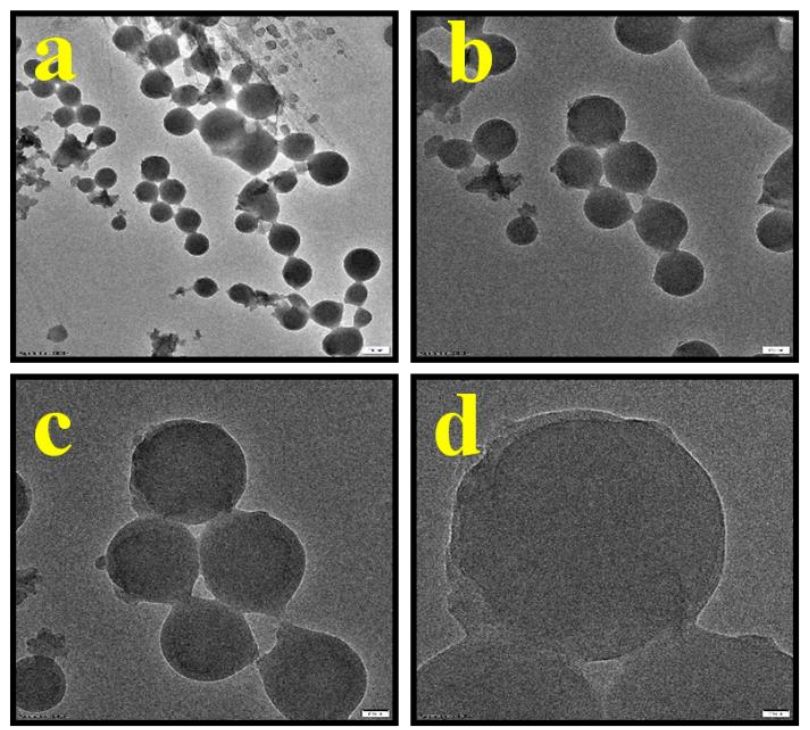

Fig. 5 - HR-TEM images of activated carbon

\section{CONCLUSIONS}

In the present work, the activated carbon was synthesized from low-grade coal through ultrasonic-assisted chemical activation method. Pre-treatment of coal by demineralization and de-sulphurization was performed to increase its reactivity and subsequent chemical activation with $\mathrm{NaOH}$ and $\mathrm{KOH}$ at 1:2 ratio to obtain coal derived activated carbon. Coal derived activated carbon had high carbon content, low volatile matter content and reduced total sulfur content. The high carbon content of the coal favours its use as precursor material in the synthesis of activated carbon. The present investigation shows the potential of low-grade tertiary coal as carbon precursor material to derive activated carbon which is an effort to produce value added products and maximise its sustainable utilisation. However, further investigation of the activated coal samples is required for maximising its utilization in energy applications.

\section{ACKNOWLEDGEMENTS}

Authors are thankful to Director of CSIR-NEIST for his permission to work on this MTech project work at CSIR-NEIST. SAIF-CSIR-NEIST is also thankfully acknowledged for the analytical support.

7. B.K. Saikia, R.K. Boruah, P.K. Gogoi, Bull. Mat. Sci. 30, 421 (2007).

8. B.K. Saikia, R.K. Boruah, P.K. Gogoi, J. Earth Syst. Sci. 116 No 6, 575 (2007).

9. R. Siburian, H. Sihotang, S.L. Raja, M. Supeno, C. Simanjuntak, Orient J. Chem. 34 No 1,182 (2018).

10. M.J. Rampe, V. Tiwow, J. Phys.: Conf. Ser. 1028, 012033 (2018). 


\title{
Окислювальний синтез активованого вуглецю із низькосортного індійського третинного вугілля та його хімічні характеристики
}

\author{
Phibarisha Sohtun ${ }^{1}$, Mousumi Bora ${ }^{2}$, Rupam Kataki ${ }^{1}$ Binoy K. Saikia²
}

${ }_{1}^{1}$ Department of Energy, Tezpur University, Tezpur, Assam 784028, India

2 Coal \& Energy Group, Materials Science \& Technology Division, CSIR-NEIST, Jorhat, Assam 785006, India

\begin{abstract}
Вуглецеві матеріали мають унікальні структурно-хімічні властивості, тому е привабливими для застосування в різних галузях. Вугілля доступне в достатку і є недорогим джерелом енергії. Вугілля також є основним джерелом вуглецю, який можна використовувати як прекурсор для отримання вуглецевих продуктів з доданою вартістю і, таким чином, підвищити його ефективне використання на стійкій основі. У дослідженні активований вуглець готували з третинного вугілля, отриманого 3 північно-східного регіону Індії. Процес підготовки складався з попередньої обробки вугілля шляхом окислення 3 подальшим просоченням змішаними лугами і карбонізаціею при $600{ }^{\circ} \mathrm{C}$. Синтезовані зразки були охарактеризовані за допомогою наближеного та елементного аналізу, аналізу сірки, аналізу площі поверхні та розміру пор, просвічуючої електронної мікроскопії (TEM), індрачервоної спектроскопії з перетворенням Фур'є (FTIR) та аналізу порошкової рентгенівської дифракції (XRD). Результати показують, що отриманий активований вуглець має покращену питому площу поверхні та розмір пор після хімічної активації і має аморфну, мікромезопористу природу. Таким чином, низькосортне індійське третинне вугілля є потенщійним джерелом для отримання вуглецевих продуктів з високою доданою вартістю на основі активованого вуглецю.
\end{abstract}

Ключові слова: Вуглецевий матеріал, Індійське вугілля, Третинне вугілля, Хімічна активація, Активований вуглець. 